\title{
The Case For Context: Eisenhower Post-Revisionism and Third World Nationalism | Seth Draine
}

In this historiography, the conclusions made by historians of the revisionist camp that assert the hidden handed yet ultimately successful legacy of President Dwight D. Eisenhower is placed under review by considering the work of post-revisionist scholars' assessment of the Eisenhower administration's foreign policy decisions during the 1950s. Specifically, the insights and arguments made by such scholars suggest that the administration's hasty use of covert action in Guatemala, Iran, and Indonesia failed to recognize national movements and histories, ultimately leading to detrimental effects to both citizen and state. Rather than damn the Eisenhower administration from the safety of hindsight, this paper seeks to give context to this crucial period in American and world history by complicating our understanding of Cold War foreign policies to include geopolitical and economic strategies as well as a deconstruction of the post-colonial environment in which such decisions were enlisted. It will conclude that although Eisenhower's ultimate goal was to avoid the casualties of conventional global war and the devastation of nuclear aggression, the covert actions pursued during his time in office and the atrocities accrued within the Third World must be given more weight when assessing the president's legacy.

\section{A Curious Elixir: Medicinal Beer in the Age of Prohibition | Andrew Engdahl}

Though it may be seen as outlandish by modern medical standards, alcoholic beverages were widely prescribed as a form of medicine prior to the advent of Prohibition in the United States. In fact, "medicinal beer," specifically, was so widely accepted for its importance as a therapeutic agent that the question of its viability caused a determined group of American physicians to launch a legislative battle that had a lasting impact on the domestic politics of the United States in the early 1920s. Although The New York Times covered this debate extensively from 1909 to 1922, the movement for medicinal beer has largely remained a historical 
enigma of the early twentieth century. I aim to argue that the debate over the validity of this curious elixir led several American doctors to join together to form the first solid legislative resistance movement to the restrictions of the Eighteenth Amendment. This paper will initially explore the traditional uses of medicinal beer in the late 1800 s, the debate over the therapeutic merits of beer within the medical community at the turn of the century, and the various internal and external factors that influenced the rise of the movement. Furthermore, I will illustrate the major elements of the medicinal beer movement after the passing of the Eighteenth Amendment, discuss the motivations and actions of the major supporters and opponents of the movement, and ultimately elaborate on how the movement failed to re-legalize beer. Though these obstinate physicians stood together in the name of beer, the focus of their ire did not revolve around the questionable therapeutic benefits of the dubious brew alone; in the eyes of the medical community, the government had overstepped its bounds by trying to control what a physician could determine to be medicine.

\section{Hanging Prosperity on a Wall: Private Art Collecting as Conspicuous Consumption, United States, 1945-1960 | Elise Erb}

Thorstein Veblen laid forth the theory of conspicuous consumption in 1902, but his ideas were perfectly suited to the art collecting tendencies of the American social elite after the Second World War. This conspicuous consumption was demonstrated in the world of private art collecting in three primary ways. The first manner in which the social elite demonstrated their wealth though the art market was by purchasing art. Whether or not a new piece was acquired at a sale, just having the time to attended demonstrated wealth. The second way that conspicuous consumption was demonstrated in the art market was through owning pieces that held status in the art world. This status was acquired through attributes such as artist, style, and the previous history of the piece. The final way that conspicuous consumption was practiced was through the advertisement of art acquisition in the newspapers, both before and after the sales. All of 
these efforts put together made art collecting in the period right after the Second World War more about making a social statement than making a cultural or economic statement. Private art collecting after the Second World War served as a perfect vehicle for the American elite to show their wealth.

\section{From Novelty to New Art: The Evolution of the Intellectual Critics' Opinion of Talkies | Samantha Hennes}

This essay focuses on the critical reception of early talkie films and how this critical consensus of the artistic value of the talkie film changed over time. Rather than examine mainstream critics of the era this essay looks at the intellectual critic who represented a different class of movie-going citizens. The intellectual critic hated the talkie when it first arrived, however, as they began to look at talkies with different aesthetic standards their views on the talkie became more positive. By using movie reviews and essays written by famous intellectual critics spanning a period of about three years, this essay comes to the conclusion that movies were not the only thing that changed with the introduction of sound, but rather the way that intellectual critics viewed movies changed as well.

\section{Ambiguous Identity: The Question of Middle Class in Late Imperial Russia | Elizabeth Metelak}

In most understandings, the middle class stands as one of the unique and defining factors of the modern era. While most American and European analysis characterizes the middle class as the driving force of modern society and politics, historians should proceed with caution when expanding these ideas to the case of the late Russian Empire. For this paper, I have focused on a variety of publications - novels, newspaper articles, plays, and philosophical essays - in order to unravel the various levels and interactions that define the Russian middle class. Through my analysis of literature and public actions, I conclude that Russia's middle class actually formed in three layers of wealth and refinement defined most accurately by the ambiguities between them rather than their marked differences. Moreover, the internal and external conflicts faced by these categories undermined the political and social influence of the middle class within 
the empire. These conclusions present a Russian middle class decidedly different from the middle classes often presented in Western scholarship, challenging assumptions that the middle class develops along a universal pattern and plays the same roles regardless of historical context. to learn the ways of the ruling class.

\section{Between Domesticity and Revolution: Inherent Contradictions in the Early Women's Rights Movement | Laura Neylan}

The purpose of this paper is to analyze how A Domestic History of the American Revolution reflects the time period in which it was written: 1850. Elizabeth Fries Ellet authored this account of the American Revolution amidst a transitional period for women's rights. The fact that a female wrote the book is notable, yet the contradictory portrayal of women in the book is even more compelling. Ellet conveys that women challenged their stereotypical gender sphere during the revolutionary conflict and yet simultaneously depicts women in a stereotypical, virtuous manner. This contradiction reflects the competing ideas on women's rights during this period. The Declaration of Rights and Sentiments was created two years before the publication of Ellet's work, which suggests that ideas about female equality would have been familiar to Ellet. However, the ideology of the cult of domesticity - the notion that women belonged at home-was also prevalent at this time. Thus the dualistic portrayal of women by Ellet in her work reflects these contradictory ideas.

\section{From the Darkness to the Family: Evolving Orientalist Representations of the Katipunan in Euro-American Travel Literature, 1899-1917 |} Andrew Pagan

On July 7, 1892 in the Philippines, Andres Bonifacio founded the Katipunan, a revolutionary society intent on the elimination of Spanish rule from the region. Despite the high hopes of many Katipuneros, Spanish control did not cease until American forces claimed sovereignty over the Philippine Islands in 1898. The United States quickly established control over the Philippines, crushing militant Filipino resistance in a two year conflict they termed the "Philippine Insurrection," but Filipinos more accurately refer to it as "The Philippine-American War." In the early 
twentieth century, European and American travelers penned firsthand accounts of the Philippines, describing various aspects of Filipino culture, life, and history. Previous examinations of these documents have proven partially successful in terms of constructing a history of the region, but too few scholars have spent time examining the motivations and prejudices behind these works. I suggest that American and European portrayals of the Katipunan from 1899-1917 evolved over time to justify changing American colonial policies in the Philippines. Travelogues published during the years of the Philippine-American War consistently stressed the "secret" and "mysterious" natures of the Katipunan in order to imply that the Philippine people did not share their revolutionary goals. Later, while the United States made it imperial policy to aid their "little brown brothers," travel account discourse functioned to characterize the Katipunan as an organization that suffered under the cruelty of the Spanish, and, like the rest of the Filipino people, required American aid and direction.

\section{A New Era In American Foreign Policy: Jimmy Carter, Human Rights And Iran | Elena Reynolds}

Jimmy Carter, of all United States presidents, was perhaps the most passionate advocate of human rights. Upon assuming the presidency, Carter announced the beginning of a new era in American foreign policy-one centered on human rights. His hope was to see his "fundamental tenet" realized throughout the world. Having witnessed mistreatment and injustice throughout his childhood in segregated southern Georgia, Carter felt compelled to make the world a better place-a place where men and women could experience true freedom. For him, human rights meant more than ending arbitrary torture, arrest, and imprisonment. It demanded the active pursuit of democratic principles, including the restoration of morality and the implementation of racial, religious, and gender equality. To accomplish these goals, the United States would have to lead by example. However, trying to convince world leaders to stop their oppressive ways was no easy task. This essay will focus specifically on Iran, the country that challenged Carter's human rights vision the most. First, it will explore how Carter's fundamental tenet shaped his policies in Iran. Second, it will examine whether or not his human rights 
policies were to blame for the Islamic Revolution and the Islamization of Iran. Third, it will seek to determine the success or failure of his human policies in Iran and as a whole.during the years of the PhilippineAmerican War consistently stressed the "secret" and "mysterious" natures of the Katipunan in order to imply that the Philippine people did not share their revolutionary goals. Later, while the United States made it imperial policy to aid their "little brown brothers," travel account discourse functioned to characterize the Katipunan as an organization that suffered under the cruelty of the Spanish, and, like the rest of the Filipino people, required American aid and direction.

\section{British and Dutch Perceptions of Cannibalism in Borneo, 1882-1964 | Adrienne Smith}

In the nineteenth century, Europeans occupied Southeast Asia seeking to spread trade and colonial rule. British and Dutch travelogues written during 1800-1905 often contained accounts of cannibalism in Borneo. Motivated by imperialism, and a fascination with cannibals, Europeans ventured further into Borneo's interior to learn more about these tribes while gradually establishing colonial rule. The way these travelogues conveyed Borneo cannibalism contributed greatly to the impression of the Orient in Europe. The logs depicted the indigenous people as savage and desperate, shaping how Europeans rationalized bringing the values of the West to Borneo. British and Dutch perception of Borneo cannibalism defined the indigenous people as barbaric and justified European colonization.

\section{Fashion and Feminism: The Mass Mockery of Twentieth Century Suffragettes | Nicola Williams}

A vast array of historical research has been conducted that relates to the struggle of earlier suffragettes in the United States, but far less attention has been paid in this sense to later waves of the suffragette movement. It is important for historians not to make the teleological mistake that as 1920 and women's suffrage approached, the women's fight became increasingly easier. For this paper I have used the New York Times as a limiting lens through which to analyze the reaction to women's suffrage during 
these later periods in the United States. Through my analysis of letters, articles and cartoons, I have managed to conclude that as 1920 approached, men and women who valued conventional expectations regarding gender stratification, became increasingly scared of the potential for change generated by the suffragettes. This same collection also prove that instead of trying to unite the public against suffragettes purely through political argumentation, these traditionalists advertised a mockery of women's fashion as a tangible, highly relatable way to suggest that women lacked the mental sense required for voting. As opposed to other research, which has revealed occasional, brash forms of opposition to the suffragettes at their rallies, my research suggests that this ridicule was continuously pervasive around New York City, on a daily basis. My research, using primary sources from New York City, commonly known as the birthplace of the Women's Rights Movement, makes a valuable contribution to the historical record by complicating the accepted, over-simplified picture of the suffragette movement. 